\title{
The Role of Venture Capital in the Commercialization of Cleantech Companies
}

\author{
SHAH RUKH SHAKEEL \\ University of Vaasa, Finland \\ shah.rukh.shakeel@univaasa.fi \\ OSKAR JUSZCZYK \\ University of Vaasa, Finland \\ oskar.juszczyk@univaasa.fi
}

Venture Capital (vc) plays an important role in the success of their portfolio companies. Small- and medium-sized companies often struggle with the resources required to succeed in the market. vc not only helps companies with the required financing but also provides the knowledge, understanding and expertise required to excel in the market. The study explores vc non-financial value-added contributions in the commercialization of clean technologies. Cleantech is a term associated with the companies involved with technologies, products, processes or services that seek to lower the negative environmental impact by improving efficiencies, reducing waste, encouraging the use of sustainable sources and environmental protection. However, the success of companies operating in this sector, at times, becomes challenging since these technologies are often disruptive in nature, contest business-as-usual practices by inducing efficiencies in the current processes or radically transforming the existing infrastructures. This qualitative case study is based on five companies operating in the Finnish clean technology sector. Data is collected in the form of semi-structured interviews whereas within the case and cross-case analysis approach is adopted to gain a comprehensive understanding of the studied phenomena. This study delineated vc's contribution to technology development, corporate governance, mentoring \& industry expertise, recruitment, collaboration \& internationalization, acquiring additional financing and certification effect. The findings of this research provide important insights for the industry specialists, managers as well as the scientists involved in this field of research.

Key words: venture capital, non-financial value addition, clean technology, commercialization

https://doi.org/10.26493/1854-4231.14.325-339

\section{Introduction}

Venture capital (vc) can play an important role in assisting companies in successfully commercialize their technologies (Samila and 
Sorenson 2010). Klofsten (1999) states that bringing new technologies to the market is a challenging and resource-intensive process requiring a huge amount of money, knowledge, skills and understanding of the market. The evidence suggests that a number of disruptive solutions have failed to become successful in the market due to their inability to cope up with the challenges and complexities faced during the process of commercialization (Bocken 2015). Venture capital can help companies in addressing these challenges by providing necessary financing, knowledge, understanding and expertise required to excel in the market (Hellmann and Puri 2002). The contribution becomes even more important for start-ups and small- and medium-sized enterprises (SMEs) as these are often characterized by limited human and financial resources (Hsu 2006). There is plentiful evidence to support the proclamation that vc involvement was a critical factor in ensuring the effective commercialization of various business initiatives across the globe (Kerr Lerner, and Schoar 2014). However, the having vc on board is not always an assurance for success as there are many examples where collaborating with vc have led to the less desired results, often in the form of failures and bankruptcies of the incumbent companies (Busenitz, Fiet, and Moesel 2004; Gaddy et al. 2017). Research conducted by Popov and Roosenboom (2012) and Hsu (2007) found that collaborating with venture capital has helped companies in developing core technology, finding collaboration partners and improving the legitimacy of the company. On the other hand, authors such as Dimov and de Clercq (2006) and Anokhin, Wincent, and Oghazi (2016) have presented cases where collaboration with vc has adversely affected companies' performance. Ghosh and Nanda (2010), Guler (2007) and Anokhin (2006) studied the causes of the failure and identified that lack of industry-specific specialization, high technology risk, accelerated exit plans or opting for less suitable deals are some of the causes of these failures.

Kaplan and Strömberg (2000) state that the level of vc's involvement and the type of input towards its portfolio businesses may differ in distinctive perspectives and industries. The existing studies have explored vc's contribution in the conventional industries (Dushnitsky and Lavie 2010; Maula, Autio, and Murray 2010; Bertoni, Colombo, and Grilli 2011), however, the literature concentrating on the contributions of vc in the Cleantech is rather limited (Bürer and Wüstenhagen 2009; Marcus, Malen, and Shmuel 2013; Cumming, Henriques, and Sadorsky 2016) and has scarcely been studied in the context of Finland. The novelty of this research, therefore, is that 
it seeks to explore vc value-added contributions in Finnish-based Cleantech companies. ${ }^{1}$ Finland offers a unique case to study venture capital's value-added contribution in the Cleantech companies for two reasons. Firstly, the country is ranked as one of the leading countries when it comes to innovating new technologies. According to the latest Bloomberg Innovation Index (Jamrisko, Miller, and Lu 2019) and The Consumer Technology Association ranking (2019), Finland is the third most innovative country in the world, while it ranked at number two when it comes to clean technologies (The Global Cleantech Innovation Index 2017 2017). The innovation input, public R\&D and innovation culture are some of the driving factors, however, the country is found to be lagging behind when it comes to commercialization (Shakeel, Takala, and Zhu 2017). Secondly, the country is considered as a great start-up hub (Business Finland 2019) attracting substantial investments in conventional as well as environmentally friendly technologies (European Chamber 2019; Näyhä 2019). Therefore, it offers an interesting case to explore venture capital's value-added contributions in the Cleantech companies operating in Finland. The remaining parts of this article are structured as follows. The second section presents a literature review, the third section details the methods adopted whereas the fourth section presents analysis followed by the fofth section presenting discussion and conclusion.

\section{Literature Review}

vc's non-financial value-added contribution has grown as an important field of research. A number of studies have explored vc contribution to technology development (Chen 2009; Lahr and Mina 2016). The literature on vc is rather rich and comprehensively explains certain types of possible vc input. The review of the literature reveals that collaborating with venture capital can have a mixed result i.e. it can help companies in ensuring success or can also cause companies to struggle. Nevertheless, a vast stream of research concludes that the influence is positive (Samila and Sorenson 2011; Sørheim 2012). Gorman and Sahlman (1989) classify the value-added contributions of vcs and point out that vc support can be observed in finding supplementary financing, strategic development, operational planning, management recruitment presentation to potential customers and suppliers and resolving compensation concerns (Gorman and Sahlman 1989). In their analysis of 20 peerreviewed articles on studying vcs value-adding performances Large and Muegge (2008) recognize ten different value-adding services 
provided by vcs. Contributions made on the external fronts are legitimation and outreach, whereas internal ones deal with recruitment, strategy, consultation, operation, mentoring and mandating.

Burt (1992), Aoki (2000), Gans, Hsu, and Stern (2002) and Lindsey (2002) state that venture capital can also serve their portfolio companies as information intermediaries, ensuring privileged business networking information access and decreasing exploration expenses during the process of pursuing proper cooperation partners. A study conducted by Sapienza, Manigart, and Vermeir (1996) found that relevant industry experience is vital to be able to add more value since their findings have shown that vc investors with experience from the venture's industry provided significantly more value-added than vcs without such specific industry know-how. vcs guru entrepreneurs, using their connections and knowledge, often contribute as referring points and participate in strategic planning (MacMillan, Kulow, and Khoylian 1989; Kaplan and Schoar 2005). Moreover, this reputational effect can be critical in encouraging potential stakeholders to participate in the venture's further development (De Clercq et al. 2006). Additionally, vc's informational advantages could improve timing in realizing the collaboration process as well as start-up patent productivity (Kortum and Lerner 2000). Fried and Hisrich (1995), in addition to the elements mentioned before, included moral support and discipline as a significant aspect of vc's contribution provided to the portfolio companies. Moreover, start-ups are often not yet satisfactorily developed to the extent that they could attract partners for collaboration on its own. Collaborating with vc can help in establishing contacts and finding partners. Major literature on the role of vcs has highlighted their capability to professionalize employment customs and human resources management (Cyr, Johnson, and Welbourne 2000; Hellmann and Puri 2002) as well as corporate governance (Lerner 1995; Baker and Gompers 2003).

Though, innovative technology solutions often struggle with a socalled 'valley of death' between research supported by the government and commercialization (Frank et al. 1996). To overcome this obstacle and to find a way to capitalize on the early stages of commercialization, characterized by a high level of risk, entrepreneurs usually seek to partner with vcs (Gompers and Lerner 2004). It is important to note that the interest of the venture company usually comes from the so-called 'exit' procedure (Megginson and Weiss 1991; Lerner 1994), which is generating a return through an initial public offering (IPO) or even a merger and acquisition by another 
company. Therefore, vc often enhances this procedure. Hsu (2006) argues that vc support is positively correlated with the probability of a portfolio company obtaining an IPO.

In general, vc as a financing institution improves start-up performance (Kaplan and Strömberg 2003). Kelly and Hankook (2013) in their empirical study found out that vc's financial support fosters both accelerated company's development as well as processes of innovation and commercialization of a given initiative. Moreover, it is important to note that vcs are not just passive investors (Samila and Sorenson 2010). Many studies concluded that vcs are critical contributors not only in filling the financial gap but also in providing value-adding services such as technological, managerial and financial support or industry-specific networking as well as understanding of foreign markets (Florida and Kenney 1988; von Burg and Kenney 2000; Caselli, Gatti, and Perrini 2009; Bertoni and Tykvova, 2012; Dubocage, Rivaud-Danset, and Redis 2012). As can be observed, vc's contribution is of various and wide-range forms, and in the rapidly changing environment it is difficult to determine and put them all together, which simply means that any list of such types cannot be treated as exhaustive.

\section{Methods of the Study}

The aim of the study i.e. to explore venture capital value-added contribution in the commercialization of Cleantech companies and to study the phenomenon in the natural setting makes qualitative case study a suitable research approach. The case study approach is an appropriate strategy in the studied context as it provides researchers with an opportunity to study the phenomenon in detail to address the questions at hand. The purposive sampling technique was implemented to identify cases (Ritchie et al. 2013). We have studied five firms operating in the Cleantech sector in Finland, each accounting for an individual case. The incorporation of multiple cases not only provides an opportunity to enhance the validity and reliability of this research but also allows studying the cases in detail and identifying similarities and differences between each case (Eisenhardt and Graebner 2007). The details of companies and their operations are provided in table 1.

The data collection was done in the form of semi-structured interviews. The approach provides researchers with the luxury of obtaining rich information while being focused on the studied context. The respondents were either founder/cєo/board of the directors of the companies, thus had solid knowledge about the firm's history, 
TABLE 1 Case Companies Details

\begin{tabular}{lll}
\hline Company* $^{*}$ Core technology & Founded \\
\hline A & Ceramic anode-supported solid oxide cells and stacks & 2002 \\
B & $\begin{array}{l}\text { Dynamic compensation solutions for power quality, energy } \\
\text { efficiency, and grid connections }\end{array}$ & 2010 \\
& Solid oxide fuel cell (soFc) systems for distributed power & 2012 \\
C & generation & \\
D & Wave energy converters generating direct-to-grid electricity & 2008 \\
E & Auxiliary wind propulsion for ships & 2012 \\
\hline
\end{tabular}

Notes * The names of the companies are replaced with letters to ensure anonymity.

operations, and strategic plans. The companies were asked to provide detailed account of contributions the venture capital has made on different fronts, the concerns they had and the challenges faced. The interviews were transcribed and the summary was shared with the interviewees to avoid any misunderstanding as well as to ensure that their viewpoint is well understood and presented.

The data triangulation technique was implemented to enhance reliability and ensure the accuracy of the findings. The sources of supplementary data include case companies' websites, press releases, news articles, and industry analysis. Within case analysis and crosscase analysis methods have helped in scrutinizing each case as well as to perform a comparative analysis of case companies.

\section{Analysis - vc Contribution Categories}

The vc firm's value-added contribution can be observed in various forms. Table 2 presents the vc value-added contributions observed in the case companies. We have grouped each vc contribution category into three levels based on venture capital's contributions. To recognize the extent of contribution and the amount of engagement, we have scaled the contribution from insignificant, to moderate, and high. Insignificant refers to minimal to no contribution, while high means that the vc has contributed significantly. Moreover, we have developed a Venture Capital Contribution Matrix (figure 1), taking into account both the extent and engagement levels. Engagement refers to whether a vc has been directly involved in the process, contributed indirectly, or not played any role in the investigated aspect at all. In order facilitate the analysis and ensure the readers' understanding of our research outcomes, we have indicated a representative capital letter for each contribution category in the first place, and they are following: $\mathrm{T}-$ Technology Development, $\mathrm{R}$ - Recruitment, IInternationalization and Cooperation, F - Financing, G - Corporate 
TABLE 2 Venture Capital's Contribution Categories

\begin{tabular}{lll}
\hline High & Moderate & Insignificant \\
\hline $\begin{array}{l}\text { Corporate governance, } \\
\text { monitoring \& industry ex- } \\
\text { petise }\end{array}$ & $\begin{array}{l}\text { Certification, recruitment, } \\
\text { cooperation \& internati- } \\
\text { olization }\end{array}$ & $\begin{array}{l}\text { Techology development, } \\
\text { additional financing }\end{array}$ \\
\hline
\end{tabular}

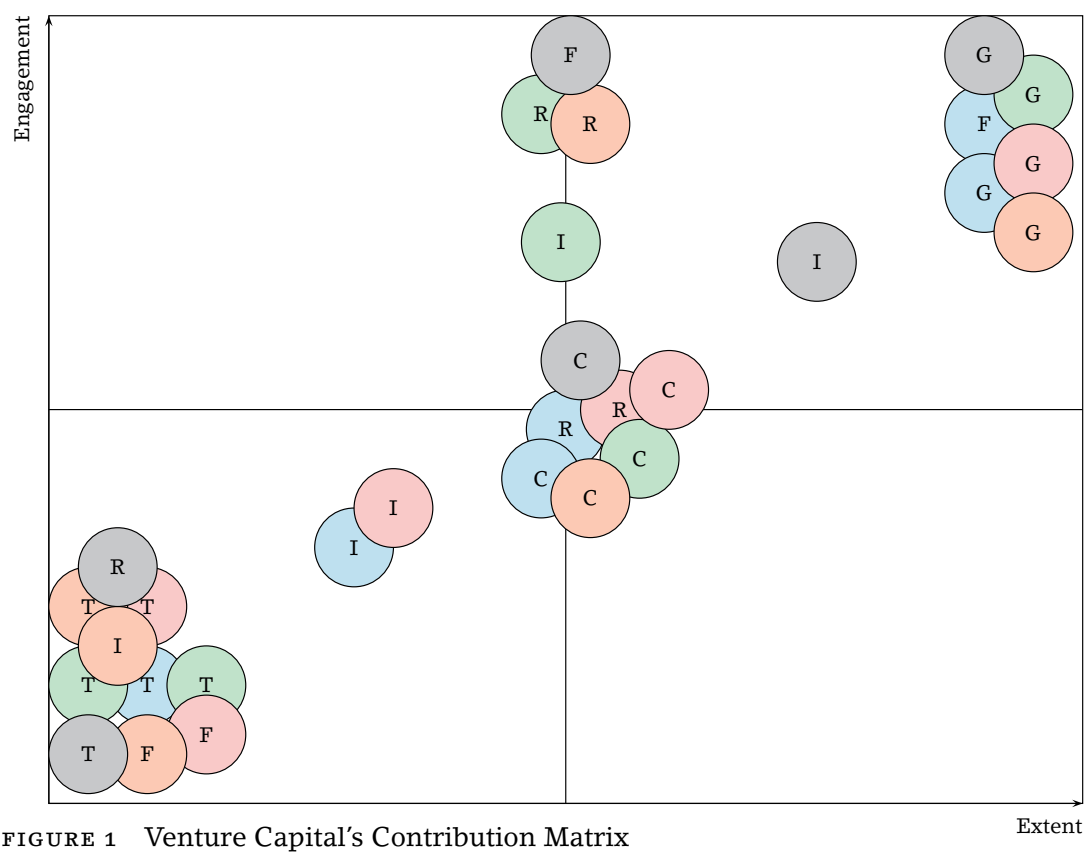

Governance, Mentoring \& Industry expertise, and C - Certification effect. After that, we presented the findings in the context of each Case Company by grouping them by colors, which are the following: $\mathrm{A}$ - green, $\mathrm{B}$ - blue, $\mathrm{C}$ - pink, D - orange, $\mathrm{E}$ - gray.

\section{TECHNOLOGY DEVELOPMENT}

Technology development can be one of the value-added benefits that vc brings to the company as suggested by (Pradhan et al. 2019). However, in our study, we have hardly seen any vc activity attributing to the direct development and shaping of the technology. Due to the complex nature of the technologies, the valuable input that can help in shaping the technology can only come up from someone who is either an expert in the field, has been working with the technology or knows the technical aspects.

The characteristics of the technology and the extent of technical 
understanding needed to make valuable contributions in technology development is the key reason why we have seen very little to no value added contribution by the vc.

CORPORATE GOVERNANCE, MENTORING \& INDUSTRY EXPERTISE

Improving the strategy and setting strategic orientation right is found to be one of the key contributions by the vc firm. The technology-based start-ups are formed by a team of technical experts, generally found to be lacking understanding of the business know-how. The portfolio companies have ranked vc contribution in this domain as of high importance. Mostly the fact of having a vc representative on the board of directors is highly appreciated by its companies. The companies which are in the early stages of development are usually running low on resources and success is often connected to supportive policies and infrastructure support. The vc companies being well connected to the industry and having knowledge of the market can provide valuable information that can help mitigate the effect of such asymmetries. The market knowledge of the vc encouraged its portfolio companies to fasten the process and develop the technology quicker and better than the competitors. Access to the resources necessary to perform various tasks is also a valuable contribution that vc brings to the table. Moreover, a fact of having past experience of working with a firm ensures that the portfolio company can immediately find the required resources without needing to go through an extensive market search process and finding a reliable partner. It reduces the time, efforts and associated transactional costs.

\section{RECRUITMENT}

Team building is one of the domains where vc tends to contribute. The contribution may come in the form of recruiting new people, making changes in the top management or restructuring of the core team. The vc is mostly active in assisting with profiling and suggesting what sort of person could be suitable, which sectors to look at, how much resources should be dedicated and how the compensation plan should be. However, in the example of one case company, vc was directly involved in the recruitment process, as there came a time when they needed to establish an office in Finland. The vc helped the company in setting up the office, building a competent team and discussing on setting compensation packages. Similarly, in the situation of another firm the suggestion was made that the company should look to hire a new cEo. At the same time, the existing 
$\mathrm{CEO}$, an engineer knowledgeable in technology development could have more time to spend on improving the technology, reducing the cost and making it more efficient. The new cEO was proposed by the vc.

\section{COLLABORATION \& INTERNATIONALIZATION}

Working with vc can offer an excellent opportunity to collaborate with the portfolio companies who are in a relatively similar stage of development and operating in similar markets. In the case of its two companies, the vc firm provided an opportunity to collaborate with each other to develop the technology further, share their experiences and learn from each other. Nevertheless, the collaboration should be a voluntary act and firms involved in partnership should decide by themselves whether or not they wish to establish such type of cooperation.

Moreover, internationalization is an important area where vc can assist companies (Lutz and George 2012). Due to the small local market, technology companies have very little choice apart from looking for customers and projects in the international market. vc has used its connections to find partners to expand its portfolio companies' operations.

\section{ACQUIRING ADDITIONAL FINANCING}

vc supports companies in fulfilling their financial needs through an investment. However, in most of the cases, vc is not the only investor in a portfolio company. The company may need additional financing from different sources such as bank loans, business angels, crowdsourcing, and grants. vc can help companies in finding this additional financing, as witnessed in the situation of one case company, which acquired financing from two vcs. The second vc firm was involved in the process through the connection initiated by the first vc. In the instance of another company, vc assisted the company in applying for an EU grant. Similarly, in one case company, the vc used its connections and involved a multinational business entity to invest in its portfolio company.

\section{CERTIFICATION EFFECT}

Improving the company's image and the legitimization is similarly an essential aspect that vcs contribute. Having vc on board, in itself, signals the company has a potential and the technology may offer a unique value proposition. In such situations, having a vc on board 
is certainly helpful. However, in some cases, it may not have the expected outcome. This is no secret that vcs' investments in the portfolio company are for profit-oriented and thus they are constantly looking for the exit procedure. This situation might be concerning for prospective allies if they are seeking for a long-perspective partnership.

\section{Discussion and Conclusion}

This section concisely presents the extent to which vcs have provided a benefit to the portfolio companies. The analysis highlights that shaping the strategic orientation right is one of the contributions that has been valued highly, both by the case companies and the vcs. The understanding required keeping the business operations running optimally, taking care of business, marketing, and management related issues often seemed lacking within the core teams, comprising mostly of technical experts. The vcs' experience and expertise in working with such projects can bridge this gap. The additional challenge that companies face in Finland is a small domestic market (de Jong et al. 2015). The companies often feel a need to go international from a very early stage to thrive and gain access to a large customer base. vc can provide market knowledge, network, and contacts needed to make these big steps in the foreign markets.

The analysis reveals the importance of having open communication between the portfolio companies and the vcs regarding how the business should be taken further. A company having a vc on board may leave the business-related activities like financing, finding partners and strategy setting for the vc so that the core team could focus on the technology development aspects. Moreover, when it comes to creating trust, collaborating with vc has a dual consequence. A vc can help in establishing sureness with the prospective partners who are fearful of companies' resources; however, it can also result in uncertainties for those who wish to form long-lasting business alliances with a vc-backed firm.

\section{Notes}

1 Cleantech is a term associated with the companies involved with technologies, products or services that seeks to lower the negative environmental impact by brining efficiencies, reducing waste, encouraging the use of sustainable sources and environmental protection. Cleantech companies can be characterized by high investments ventures, usually operates in rapidly changing business environment, have relatively longer payback time and often require adaptive changes in the existing infrastructure.

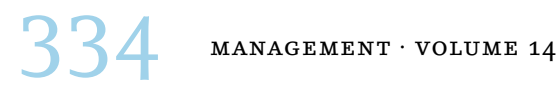




\section{References}

Anokhin, S. 2006. 'Empirical Essays on Corporate Innovation: Untangling the Effects of Corporate Venture Capital.' PhD dissertation, Case Western Reserve University.

Anokhin, S., J. Wincent, and P. Oghazi. 2016. 'Strategic Eeffects of Corporate Venture Capital Investments.' Journal of Business Venturing Insights 5:63-69.

Aoki, M. 2000. 'Information and Governance in the Silicon Valley Model.' In Corporate Governance: Theoretical and Empirical Perspectives, edited by X. Vives, 169-96. Cambridge, mA: Cambridge University Press.

Baker, M., and P. A. Gompers. 2003. 'The Determinants of Board Structure at the Initial Public Offering.' The Journal of Law and Economics 46 (2): 569-98.

Bertoni, F., and T. Tykvova. 2012. 'Which Form of Venture Capital is Most Supportive of Innovation?' zew Discussion Papers 12-018, Zentrum für Europäische Wirtschaftsforschung, Leibniz.

Bertoni, F., M. G. Colombo, and L. Grilli. 2011. 'Venture Capital Financing and the Growth of High-Tech Start-Ups: Disentangling Treatment from Selection Effects.' Research Policy 40 (7): 1028-43.

Bocken, N. M. 2015. 'Sustainable Venture Capital - Catalyst for Sustainable Start-Up Success?' Journal of Cleaner Production 108:647-58.

Burt, R. S. 1992. Structural Holes: The Social Structure of Competition. Cambridge, mA: Harvard University Press.

Busenitz, L. W., J. O. Fiet, and D. D. Moesel. 2004. 'Reconsidering the Venture Capitalists' "Value Added" Proposition: An Interorganizational Learning Perspective.' Journal of Business Venturing 19 (6): 787-807.

Business Finland. 2019. 'Finnish Startup Scene.' https://www .businessfinland.fi/en/do-business-with-finland/invest-in-finland/ why-invest-in-finland/vibrant-startup-scene

Bürer, M. J., and R. Wüstenhagen. 2009. 'Which Renewable Energy Policy Is a Venture Capitalist's Best Friend? Empirical Evidence from a Survey of International Cleantech Investors.' Energy Policy 37 (12): 4997-5006.

Caselli, S., S. Gatti, and F. Perrini. 2009. 'Are Venture Capitalists a Catalyst for Innovation?' European Financial Management 151:92-111.

Chen, C. J. 2009. 'Technology Commercialization, Incubator and Venture Capital, and New Venture Performance.' Journal of Business Research 62 (1): 93-103.

Cumming, D., I. Henriques, and P. Sadorsky. 2016. “"Cleantech” Venture Capital around the World.' International Review of Financial Analysis 44:86-97.

Cyr, L. A., D. E. Johnson, and T. M. Welbourne. 2000. 'Human Resources 
in Initial Public Offering Firms: Do Venture Capitalists Make a Difference?' Entrepreneurship Theory and Practice 25 (1): 77-92.

De Clercq, D., V. H. Fried, O. Lehtonen, and H. J. Sapienza. 2006. 'An Entrepreneur's Guide to the Venture Capital Galaxy.' Academy of Management Perspectives 20 (3): 90-112.

de Jong, J., E. von Hippel, F. Gault, J. Kuusisto, and C. Raasch. 2015. 'Market Failure in the Diffusion of Consumer-Developed Innovations: Patterns in Finland.' Research Policy 44 (10): 1856-65.

Dimov, D., and D. De Clercq. 2006. 'Venture Capital Investment Strategy and Portfolio Failure Rate: A Longitudinal Study.' Entrepreneurship Theory and Practice 30 (2): 207-23.

Dubocage, E., D. Rivaud-Danset, and J. Redis. 2012. 'Success or Failure of French New Technology-Based and Venture-Backed Companies: an Empirical Approach.' http://papers.ssrn.com/sol3/papers.cfm ?abstract_id=2148424

Dushnitsky, G., and D. Lavie. 2010. 'How Alliance Formation Shapes Corporate Venture Capital Investment in the Software Industry: A Resource-Based Perspective.' Strategic Entrepreneurship Journal 4 (1): $22-48$.

Eisenhardt, K. M., and M. E. Graebner. 2007. 'Theory Building From Cases: Opportunities And Challenges.' Academy of Management Journal 50 (1): 25-32.

European Chamber. 2019. 'Best European Countries for Business 2019.' https://eucham.eu/best-european-countries-for-business-2019/

Florida, R., and M. Kenney. 1988. 'Venture Capital and High Technology Entrepreneurship.' Journal of Business Venturing 3 (4): 301-19.

Frank, C., C. Sink, L. Mynatt, R. Rogers, and A. Rappazzo. 1996. 'Surviving the Valley of Death: A Comparative Analysis.' The Journal of Technology Transfer 21 (1-2): 61-69.

Fried, V. H., and R. D. Hisrich. 1995. 'The Venture Capitalist: A Relationship Investor.' California Management Review 37 (2): 101-13.

Gaddy, B. E., V. Sivaram, T. Jones, and L. Wayman. 2017. 'Venture Capital and Cleantech: The Wrong Model for Energy Innovation.' Energy Policy 102:385-95.

Gans, J. S., D. H. Hsu, and S. Stern. 2002. 'When Does Start-Up Innovation Spur the Gale of Creative Destruction?' The RAND Journal of Economics 33 (4): 571-86.

Ghosh, S., and R. Nanda. 2010. 'Venture Capital Investment in the Clean Energy Sector.' Hвs Entrepreneurial Management Working Paper 11-020, Harvard Business School, Boston, MA.

Gompers, P. A., and J. Lerner. 2004. The Venture Capital Cycle. Cambridge, MA: MIт Press.

Gorman, M., and W. A. Sahlman. 1989. 'What do Venture Capitalists Do?' Journal of Business Venturing 4 (4): 231-48. 
Guler, I. 2007. 'Throwing Good Money after Bad? Political and Institutional Influences on Sequential Decision Making in the Venture Capital Industry.' Administrative Science Quarterly 52 (2): 248-85.

Hellmann, T., and M. Puri. 2002. 'Venture Capital and the Professionalization of Start-Up Firms: Empirical Evidence.' The Journal of Finance 57 (1): 169-97.

Hsu, D. 2006. 'Venture Capitalists and Cooperative Start-Up Commercialization Strategy.' Management Science 52 (2): 204-19.

- 2007. 'Experienced Entrepreneurial Founders, Organizational Capital, and Venture Capital Funding.' Research Policy 36 (5): 72241.

Jamrisko, M., L. J. Miller, and W. Lu. 2019. 'These Are the World's Most Innovative Countries.' https://www.bloomberg.com/news/articles/ 2019-01-22/germany-nearly-catches-korea-as-innovation-champ -u-s-rebounds

Kaplan, S., and A. Schoar. 2005. 'Private Equity Performance: Returns, Persistence and Capital Flows.' Journal of Finance 6o (4): 1781-823.

Kaplan, S. N., and P. Strömberg. 200o. 'How Do Venture Capitalists Choose Investments?' Working Paper, University of Chicago, Chicago.

- 2003. 'Financial Contracting Theory Meets the Real World: An Empirical Analysis of Venture Capital Contracts.' Review of Economic Studies 70 (2): 281-315.

Kelly, R. and K. Hankook. 2013. 'Venture Capital as a Catalyst for High Growth: Industry Canada.' ERPA Working Paper Series 201301, Economic Research and Policy Analysis Branch, Canada.

Kerr, W. R., J. Lerner, and A. Schoar. 2014. 'The Consequences of Entrepreneurial Finance: Evidence from Angel Financings.' Review of Financial Studies 27 (1): 20-55.

Klofsten, M. 1999. 'Supporting the Pre-Commercialization Stages of Technology-Based Firms: The Effects of Small-Scale Venture Capital.' Venture Capital: An International Journal of Entrepreneurial Finance 1 (1): 83-93.

Kortum, S., and J. Lerner, J., 2000. 'Assessing the Contribution of Venture Capital to Innovation.' The RAnd Journal of Economics 31 (4): 674692.

Lahr, H., and A. Mina. 2016. 'Venture Capital Investments and the Technological Performance of Portfolio Firms.' Research Policy 45 (1): 303-18.

Large, D., and S. Muegge. 2008. 'Venture Capitalists' Non-Financial Value-Added: An Evaluation of the Evidence and Implications for Research.' Venture Capital: An International Journal of Entrepreneurial Finance 10 (1): 21-53.

Lerner, J. 1994. 'The Syndication of Venture Capital Investments.' Financial Management 23 (3): 16-27. 
1995. 'Venture Capitalists and the Oversight of Private Firms.' The Journal of Finance 50 (1): 301-18.

Lindsey, L., 2002. 'The Venture Capital Keiretsu Effect: An Empirical Analysis of Strategic Alliances among Portfolio Firms.' SIE PR Policy Paper 02-017, Stanford Institute of Economic Policy Research, Stanford, cA.

Lutz, E., and G. George. 2012. 'Venture Capitalists' Role in New Venture Internationalization.' The Journal of Private Equity 16 (1): 26-41.

Macmillan, I. C., D. M. Kulow, and R. Khoylian. 1989. 'Venture Capitalists' Involvement in Their Investments: Extent and Performance.' Journal of Business Venturing 4 (1): 27-47.

Marcus, A., J. Malen, and E. Shmuel. 2013. 'The Promise and Pitfalls of Venture Capital as an Asset Class for Clean Energy Investment: Research Questions for Organization and Natural Environment Scholars.' Organization \& Environment 26 (1): 31-60.

Maula, M., E. Autio, and G. Murray. 2010. 'Corporate Venture Capitalists and Independent Venture Capitalists: What Do They Know, Who do They Know and Should Entrepreneurs Care?' Venture Capital: An International Journal of Entrepreneurial Finance 7 (1): 3-21.

Megginson, W. L., and K. A. Weiss. 1991. 'Venture Capitalist Certification in Initial Public Offerings.' Journal of Finance 46 (3): 879-903.

Näyhä, A. 2019. 'Transition in the Finnish Forest-Based Sector: Company Perspectives on the Bioeconomy, Circular Economy and Sustainability.' Journal of Cleaner Production 209:1294-306.

Popov, A., and P. Roosenboom. 2012. 'Venture Capital and Patented Innovation: Evidence from Europe.' Economic Policy 27 (71): 447-82.

Pradhan, R. P., M. B. Arvin, M. Nair, S. E. Bennett, and S. Bahmani. 2019. 'Short-Term and Long-Term Dynamics of Venture Capital and Economic Growth in a Digital Economy.' Technology in Society 57:125-34.

Ritchie, J., J. Lewis, C. McNaughton, and R. O. Nicholls. 2013. Qualitative Research Practice: A Guide for Social Science Students and Researchers. Thousand Oaks, cA: Sage.

Samila, S., and O. Sorenson. 2010. 'Venture Capital as a Catalyst to Commercialization.' Research Policy 39 (10): 1348-6o.

- 2011. 'Venture Capital, Entrepreneurship, and Economic Growth.' The Review of Economics and Statistics 93 (1): 338-49.

Sapienza, H. J., S. Manigart, and W. Vermeir. 1996. 'Venture Capitalist Governance and Value Added in Four Countries.' Journal of Business Venturing 11 (6): 439-69.

Shakeel, S. R., J. Takala, and L.-D. Zhu. 2017. 'Commercialization of Renewable Energy Technologies: A Ladder Building Approach.' Renewable and Sustainable Energy Reviews 78:855-67.

Sørheim, R. 2012. '7 Venture Capitalists as Smart Investors.' In Handbook of Research on Venture Capital, edited by H. Landström and C. Mason, 159-71. Cheltenham: Edward Elgar. 
The Global Cleantech Innovation Index 2017. 2017. https://wwf.fi/app/ uploads/2/n/1/5njozhvdv3luu5ebfk7urng/global_cleatech _innovation_index_2017_final_web.pdf

von Burg, U., and M. Kenney. 2000. 'Venture Capital and the Birth of the Local Area Networking Industry.' Research Policy 29 (9): 1135-55.

This paper is published under the terms of the Attribution-

NonCommercial-NoDerivatives 4.o International (CC BY-NC-ND 4.0)

License (http://creativecommons.org/licenses/by-nc-nd/4.o/). 